\title{
Editorial \\ Healthy Communities: What Have We Learned and Where do We Go from Here?
}

\author{
Jerry D. Marx \\ Department of Social Work, University of New Hampshire, Hood House, 89 Main St., Durham, NH 03824, USA; \\ Jerry.Marx@unh.edu; Tel.: +1-603-862-4728 \\ Academic Editor: Martin J. Bull \\ Received: 19 August 2016; Accepted: 22 August 2016; Published: 25 August 2016
}

Systems theory $[1,2]$ suggests that healthy communities promote healthy individual development. That is, healthy systems take care of their component parts, and they do this, in part, by conducting positive exchanges with external systems. However, the thinking on what characterizes a "healthy" community continues to change over time. Social exchange theory [3] emphasizes the norms of reciprocity and the underlying relationships of trust that develop in healthy communities. Other authors stress the need for various forms of capital, not only economic and political, but also social, environmental, cultural, and spiritual [4,5].

Contemporary theory underlying the trend towards "New Urbanism" [6] has its roots in the writings of Jane Jacobs [7]. Jacobs, a U.S. citizen, challenged the prevailing notions of urban planning in the United States, claiming that urban renewal of the 1940s and 1950s had hurt the health of cities due to single use zoning that located residents, parks, business, government services, etc. in separate sections of the city. This tended to leave these areas unused for extended periods of each day, thus isolating various groups and uses. She further insisted that high rise towers and open plazas created wind swept areas with little appeal to pedestrians, who preferred denser neighborhoods with short blocks and buildings of moderate height.

Consequently, contemporary views of "livable communities" maintain that density and diversity are good for the health of cities. Healthy communities are more pedestrian-friendly and less automobile-centric. Mixed-use zoning keeps a flow of people through streets, neighborhoods, and districts, which is good for business, safety, and tourism. Locally-sourced food is more sustainable for the environment and healthier for individuals [7-9].

But how does this all relate to the current and future provision of social services? And how should social institutions collaborate with those of the economic and political sectors to maximize individual and societal well-being? Those involved with the settlement house movement of the late 1800s and early 1900s in Great Britain and the United States certainly understood the impact of the environment on individual functioning and worked with both government and business leaders to better organize communities and services to meet the needs of residents. Deinstitutionalization and the movement toward community-based social services in the U.S. in the 1960s, 1970s, and 1980s recognized the potential positive influence of healthy communities on individual functioning [10,11].

This special collection, therefore, aims to focus on the contextual factors that characterize "healthy communities" and that impact individual development and well being around the world. Researchers from various fields including psychiatry, public health, sociology, political science, community planning, economics, kinesiology, and social work present their theoretical, empirical, or practice-based studies on critical issues involving healthy communities.

To begin, Roseland and Spiliotopoulou provide a historical overview of urban sustainability theory and practice, and explain why urban sustainability planning and development currently face limited and inconsistent application [12]. The authors argue that urban sustainability today needs "to embrace equity, inclusion, and other social considerations; encourage the integration of human and 
environmental health interests; and encompass triple-bottom-line-inspired outcomes." The authors, therefore, encourage a broad perspective on healthy communities that emphasizes social, financial as well as environmental goals.

Marx and Rataj in the second paper in this collection present a case study that illustrates this growing public concern for a broader paradigm in urban planning and community development [13]. The case study documents a successful community organizing effort to promote a more livable neighborhood in Portland, Maine (USA). In opposing a development project that had been endorsed by the city government, community activists stressed the importance of social and environmental factors impacting community health and livability. Implications for healthy communities, community activists, and social work educators are discussed.

Robinson provides a more theoretical paper on the topic of healthy communities [14]. That is, the author explores the relevance of "hybridity" for the "Kids in Communities" study-an Australian research project examining community influences on child development across multiple case study sites in that country.

Moeller, McKillip, Wienk, and Cutler also see children and families as central to sustaining healthy communities [15]. The authors provide a case study of one rural community in the U.S. that used an inquiry-based approach to address the question, "How can we engage our citizens to improve child and family well-being in our community?" Their paper describes the formation of a "community of practice," its growing links to community agencies, and its initial efforts to develop calls to action through participatory research and grassroots activism.

Holden et al. agree with Roseland and Spiliotopoulou that community health is a matter of equity and human rights [16]. They argue that addressing the complex health and well-being needs of ethnically and culturally diverse communities requires creative strategies to reduce risk factors and bolster protective factors. To this end, the authors examine strategic efforts to improve individual longevity and quality of life through accessible primary care, focused community-based programs, multi-disciplinary clinical and translational research, and effective health policy advocacy.

Buccieri contributes to this collection on reinventing healthy communities by providing a case study on planning for social housing and health care in Ontario, Canada [17]. Homelessness is a multi-dimensional social problem that requires a coordinated systems approach. In recent years, Canada has attempted to integrate health care and social care to better address the needs of homeless persons. This article documents the way in which planners for social housing and health care collaborated to align their system approaches for homeless persons.

The Great Recession created homelessness and other forms of hardship for vulnerable people in communities throughout the world. Although African Americans are generally especially hard hit by these types of economic crises, they have a long and distinctive history of community volunteerism and mutual assistance. Consequently, Carter and Marx examined African American volunteering in non-profit organizations in the aftermath of the 2008-2009 recession [18]. Specifically, the researchers use data from the Panel Study of Income Dynamics (PSID) to analyze U.S. volunteering in four categories of organizations: poverty organizations, senior service agencies, social action groups, and religious affiliated organizations. All of these organizations are part of social capital, and therefore, help to sustain healthy communities. The authors' secondary analysis produced significant findings regarding volunteerism among African Americans in these community-based organizations.

Like the Robinson study and the research by Moeller et al., Laurin, Bilodeau, Giguere, and Potvin address the topic of healthy communities from the perspective of child development. In this study, the researchers examined the decision-making process that fostered ownership of the results of the 2006 "Survey of the School Readiness of Montreal Children" [19]. Their analysis documents the impacts of those survey findings on intersectoral action regarding early childhood services. An important outcome has been closer collaboration between early childhood services and school systems. This includes the development of both transition-to-kindergarten tools and literacy activities. The authors discuss the implications for future community planning. 
Rashad and Sharaf, like other authors in this collection, stress the importance of equity to the health of communities and society at large [20]. The findings of their quantitative study in Egypt reject the hypothesis that health care subsidies mostly benefit the poor. Consequently, the researchers conclude that future poverty reduction and healthcare reform efforts in Egypt should not only expand healthcare coverage, but also on improve the equity of its distribution for poor citizens.

In the final paper, Williams-Roberts, Jeffery, Johnson, and Muhajarine stress that the concept of healthy communities actually involves a diverse set of strategies, making evaluation of health outcomes related to individual approaches critically important to sustaining such efforts [21]. Their systematic review analyzes the effectiveness in this regard of the ten most common healthy community approaches: Healthy Cities/Communities, Smart Growth, Child Friendly Cities, Safe Routes to Schools, Safe Communities, Active Living Communities, Livable Communities, Social Cities, Age-Friendly Cities, and Dementia Friendly Cities. Implications for future evaluative research are considered.

Conflicts of Interest: The author declares no conflict of interest.

\section{References}

1. Ludwig von Bertalanffy. General Systems Theory: Foundations, Development, Applications. New York: George Braziller, 1968.

2. Urie Bronfenbrenner. The Ecology of Human Development: Experiments by Nature and Design. Cambridge: Harvard University Press, 1979.

3. Peter M. Blau. Exchange \& Power in Social Life. New York: Wiley, 1964.

4. Robert D. Putnam. Bowling Alone: The Collapse and Revival of American Community. New York: Simon and Schuster, 2000.

5. Mark Roseland. Toward Sustainable Communities. Gabriola Island: New Society, 2012.

6. New Urbanism. "Principles of Urbanism." Available online: http://www.newurbanism.org/newurbanism/ principles.html (accessed on 24 August 2016).

7. Jane Jacobs. The Death and Life of Great American Cities. New York: Random House, 1961.

8. David Owen. Green Metropolis: Why Living Smaller, Living Closer, and Driving Less are the Keys to Sustainability. New York: Penguin Books, 2009.

9. Edward Glaeser. Triumph of the City. New York: Penguin, 2011.

10. Bruce Jansson. The Reluctant Welfare State: Engaging History to Advance Social Work Practice in Contemporary Society, 7th ed. Pacific Grove: Brooks Cole, 2011.

11. Jerry D. Marx. Social Welfare: The American Partnership. Boston: Allyn \& Bacon, 2004.

12. Mark Roseland, and Maria Spiliotopoulou. "Converging Urban Agendas: Toward Healthy and Sustainable Communities." Social Sciences 5 (2016): 28. [CrossRef]

13. Jerry D. Marx, and Alison Rataj. "A Case Study in Organizing for Livable and Sustainable Communities." Social Sciences 5 (2015): 1. [CrossRef]

14. Rachel Robinson. “Hybridity: A Theory of Agency in Early Childhood Governance.” Social Sciences 5 (2016): 9. [CrossRef]

15. Mary Moeller, Angela McKillip, Ruth Wienk, and Kay Cutler. "In Pursuit of Child and Family Well-Being: Initial Steps to Advocacy." Social Sciences 5 (2016): 30. [CrossRef]

16. Kisha Holden, Tabia Akintobi, Jammie Hopkins, Allyson Belton, Brian McGregor, Starla Blanks, and Glenda Wrenn. "Community Engaged Leadership to Advance Health Equity and Build Healthier Communities." Social Sciences 5 (2015): 2. [CrossRef]

17. Kristy Buccieri. "Integrated Social Housing and Health Care for Homeless and Marginally-Housed Individuals: A Study of the Housing and Homelessness Steering Committee in Ontario, Canada." Social Sciences 5 (2016): 15. [CrossRef]

18. Vernon B. Carter, and Jerry D. Marx. "US Volunteering in the Aftermath of the Great Recession: Were African Americans a Significant Factor? " Social Sciences 5 (2016): 22. [CrossRef]

19. Isabelle Laurin, Angèle Bilodeau, Nadia Giguère, and Louise Potvin. "Intersectoral Mobilization in Child Development: An Outcome Assessment of the Survey of the School Readiness of Montreal Children." Social Sciences 4 (2015): 1316-34. [CrossRef] 
20. Ahmed Shoukry Rashad, and Mesbah Fathy Sharaf. "Who Benefits from Public Healthcare Subsidies in Egypt?" Social Sciences 4 (2015): 1162-76. [CrossRef]

21. Hazel Williams-Roberts, Bonnie Jeffery, Shanthi Johnson, and Nazeem Muhajarine. "The Effectiveness of Healthy Community Approaches on Positive Health Outcomes in Canada and the United States." Social Sciences 5 (2015): 3. [CrossRef]

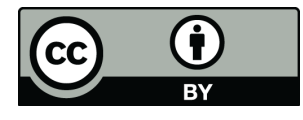

(C) 2016 by the author; licensee MDPI, Basel, Switzerland. This article is an open access article distributed under the terms and conditions of the Creative Commons Attribution (CC-BY) license (http://creativecommons.org/licenses/by/4.0/). 